\author{
Elder José Reioli Cirilo
}

\title{
Supporting Heterogeneous Configuration Knowledge of Software Product Lines
}

Thesis presented to the Programa de Pós-Graduação em Informática of the Departamento de Informática do Centro Técnico Científico da PUC-Rio, as partial fulfillment of the requirements for the degree of Doutor.

Advisor: Prof. Carlos José Pereira de Lucena 


\title{
Elder José Reioli Cirilo
}

\section{Supporting Heterogeneous Configuration Knowledge of Software Product Lines}

Thesis presented to the Programa de Pós-Graduação em Informática of the Departamento de Informática do Centro Técnico Científico da PUC-Rio, as partial fulfillment of the requirements for the degree of Doutor.

\author{
Prof. Carlos José Pereira de Lucena \\ Advisor \\ Departamento de Informática - PUC-Rio
}

Prof. Alessandro Fabricio Garcia

Departamento de Informática - PUC-Rio

Prof. Arndt Von Staa

Departamento de Informática - PUC-Rio

Prof. Paulo Henrique Monteiro Borba

Centro de Informática - UFPE

Prof. Vander Ramos Alves

Departamento de Ciência da Computação - UNB

Prof. José Eugenio Leal

Coordinator of the Centro Técnico Científico - PUC-Rio

Rio de Janeiro - April 10, 2012 
All rights reserved.

\section{Elder José Reioli Cirilo}

Doctoral and Master's Degree in Computer Science from the Pontifical Catholic University of Rio de Janeiro (PUC-Rio) and Bachelor's Degree in Computer Science from the Federal University of Juiz de Fora (UFJF).

Bibliographic data

Cirilo, Elder

Supporting Heterogeneous Configuration Knowledge of Software Product Lines / Elder José Reioli Cirilo; advisor: Carlos José Pereira de Lucena - 2012.

2 v. 104 f: il. ; $30 \mathrm{~cm}$

Tese (Doutorado) - Pontifícia Universidade Católica do Rio de Janeiro, Departamento de Informática, 2012 Inclui bibliografia.

1. Informática - Teses. 2. Linhas de Produtos de Software. 3. Frameworks Orientados a Objetos. 4. Linguagens Específicas de Domínio. 5. Ferramentas para Linhas de Produtos de Software. I. Lucena, Carlos. II. Pontifícia Universidade Católica do Rio de Janeiro. Departamento de Informática. III. Título. 


\section{Acknowledgments}

First, I give thanks to God for everything and for my beloved family. To my dear parents Maria Josefina and José Cyrilo for supporting me since I was born. To my dearest aunt, "Tia Santa", for always loving and supporting me. Even living so far during my $\mathrm{PhD}$, they were always very present. To Suelen for his love and for supporting me along the $\mathrm{PhD}$ journey. God helped us to overcome the difficulties inherent to $\mathrm{PhDs}$ - she was also doing her $\mathrm{PhD}$ at the same time. To my sisters Elisana and Elaina.

To my advisor, Carlos Lucena, who was always very supportive, and whose ideas were great inspiration to this $\mathrm{PhD}$ work. To Professors Uirá Kulesza and Alessandro Garcia for the great discussions on software product line.

To my friend and $\mathrm{PhD}$ colleague Ingrid Nunes who contributed on the empirical study performed in this work. To all my friends and $\mathrm{PhD}$ colleagues who also contributed with great discussions. To the LES research group in general for the friendship.

To the professors of the committee, Paulo Borba, Vander Alves, Arndt von Staa and Alessandro Garcia for giving great suggestions on how to improve this thesis.

To the Informatics Department, its professors and the technical staff, for supporting my research, and to CNPq, CAPES and FAPERJ for funding it. 


\section{Resumo}

Cirilo, Elder; Lucena, Carlos; Advisor. Suportando Conhecimento de Configuração Heterogêneo de Linhas de Produtos de Software. Rio de Janeiro, 2012. 104p. Tese de Doutorado — Departamento de Informática, Pontifícia Universidade Católica do Rio de Janeiro.

Softwares personalizados para as necessidades de um cliente proveem vantagem competitiva quando comparados aos softwares de proposito geral. Linhas de produtos de softwares tem como objetivo a produção de produtos personalizados a partir de um conjunto de features reutilizáveis. É conhecido que o reuso sistemático de features potencialmente leva a ganhos significativos como rápida produção de software a um baixo custo e com maior qualidade. Na prática, a construção de linhas de produtos de softwares empresariais pode se tornar uma tarefa arriscada e sujeita a erros quando se leva em consideração o uso das técnicas atuais de implementação de features. O desenvolvimento de linhas de produtos de software empresáriais de fato requer a convergência coordenada de várias visões (ex., especialistas de domínio, projetistas de interface, e desenvolvedores). Neste caso, cada participante do processo de desenvolvimento tem uma linguagem particular para resolver o problema específico a sua especialidade. Os desafios para integração de diferentes linguagens, evitando uma potencial cacofonia, é o problema do conhecimento de configuração heterogêneo. Nesta tese, nos examinamos as dificuldades atuais na especificação do conhecimento de configuração heterogêneo e como solução nos propomos a noção de Linguagens de Modelagem do Conhecimento do Domínio (LMCD). O propósito das LMCDs é evidenciar os conceitos do domínio e suas interfaces de programação, o que ajuda reduzir o ofuscamento do código fonte e aumentar a compreenssão. Além disso, evidenciando os conceitos específicos de domínio, somos aptos a prevenir inconsistências em produtos pela detecção de erros em toda a linha de produto de software. Outro resultado deste trabalho de pesquisa é GenArch ${ }^{+}$, uma ferramenta extensível que suporta de forma flexível a incorporação de LMCDs na engenharia de linhas de produtos de softwares tradicional. Nos enfatizamos os benefícios da ferramenta, incluindo simplicidade, expressividade, e a capacidade de ser independente de qualquer tecnologia de implementaçao do domínio. Finalmente, nos ilustramos e avaliamos o uso de LMCDs em três diferentes linhas de produtos de software.

\section{Palavras-chave}

Linhas de Produtos de Software; Frameworks Orientados a Objetos; Linguagens Específicas de Domínio; Ferramentas para Linhas de Produtos de Software; 
Abstract

Cirilo, Elder; Lucena, Carlos; Advisor. Supporting Heterogeneous Configuration Knowledge of Software Product Lines. Rio de Janeiro, 2012. 104p. DSc Thesis — Departamento de Informática, Pontifícia Universidade Católica do Rio de Janeiro.

Customer-specific software can provide a competitive advantage compared to general-purpose software. A software product line (SPL) aims at tailoring customer-specific products from a set of reusable features. It is well known that systematic reuse of features potentially leads to significant gains such as faster production with low costs and high quality. In practice, building enterprise software product lines might become a laborious and error-prone task when we take into account the use of current implementation techniques. Successful development of modern enterprise software product lines requires the convergence of multiple views (e.g., domain experts, interface designers, and developers), which are usually managed via domain-specific concepts. In this case, each participant of the development process has a particular working language to solve specific problems to its expertise. The challenge of integrating these differences into the engineering process, avoiding the potential cacophony of multiple different languages, is the heterogeneous configuration knowledge problem. In this thesis, we examine the current shortcomings on the specification of heterogeneous configuration knowledge and as a solution we propose the notion of Domain Knowledge Modeling Languages (DKMLs). The purpose of DKMLs is to put in evidence the domain concepts and their programming interfaces, which help to reduce source code obfuscation and increase feature comprehension. Moreover, evidencing the domain-specific concepts, we are also able to prevent inconsistencies on products by detecting errors in the entire software product line. Another result of this research is the $\mathrm{GenArch}^{+}$, an extensible tool that supports the flexible incorporation of DKMLs in traditional software product line engineering. We emphasize the benefits of $\mathrm{GenArch}^{+}$, including simplicity, expressiveness, and being framework independent. Finally, we illustrate and evaluate the use of DKMLs in three different product lines.

\section{Keywords}

Software Product Lines; Object-oriented Frameworks; Domainspecific Languages; Software Product Lines Tools; 


\section{Table of Contents}

1 Introduction $\quad 10$

1.1 Contributions 14

$\begin{array}{ll}1.2 & \text { Outline of the Thesis Structure } \\ \end{array}$

2 Problem Formulation $\quad 17$

2.1 Scenarios when Assigning Framework-based Software Product Lines Source-code to Features $\quad 22$

2.1.1 Configuration and Customization Code 22

2.1.2 Cross-references between Concept Instances 25

2.1.3 References to Concept Instances inside Customization Code 27

2.1.4 Context Sensitive Instantiation Constraints 28

2.2 Limitations of the Related Work 29

2.2.1 Annotation-based Techniques 30

2.2.2 Model-based Techniques $\quad 32$

2.3 Summary and Goals 35

3 Supporting Heterogeneous Configuration Knowledge of Software Product Lines with Domain Knowledge Modeling Languages $\quad 37$

3.1 Domain-specific model-supported Engineering of Framework-based Software Product Lines

3.2 DKML: Definition and Properties 40

3.3 Visualizing Features Code 46

3.4 Consistency Checking and Guidance 51

3.4.1 Disciplined Feature Assignment 51

3.4.2 Guidance 53

3.4.3 Consistency Checking 55

$\begin{array}{lll}3.5 & \text { Summary } & 58\end{array}$

4 GenArch $^{+}$: Building Software Product Lines with Domain Knowledge Modeling Languages $\quad 59$

4.1 Tool Architecture Overview $\quad 59$

4.1.1 Domain Knowledge Schema 60

4.2 DKML Editor and Views 62

4.3 A Language For Reverse Engineering Domain Knowledge Models 65

4.3.1 Reverse Engineering Domain Knowledge Models 67

4.4 Summary 69

5 Evaluation $\quad \mathbf{7 0}$

5.1 Selected Product Lines 70

5.2 Assessment of Modularity and Complexity 72

5.2.1 Study Phases and Analysis Procedures $\quad 72$

5.2.2 Quantitative Metrics Suite $\quad 73$

5.2.3 Results: Separation of Concerns $\quad 74$

$\begin{array}{lll}\text { 5.2.4 Results: Size } & 75\end{array}$ 
5.3 Empirical Evaluation 76

5.3.1 Experiment Hypotheses $\quad 77$

$\begin{array}{lll}\text { 5.3.2 Background of the Participants } & 77\end{array}$

$\begin{array}{lll}\text { 5.3.3 Experimental Design } & 78\end{array}$

5.3.4 Variables and Analysis $\quad 80$

5.3.5 Fist Controlled Experiment: Results, Analysis and Discussion 80

5.3.6 Second Controlled Experiment: Analysis and Discussion 85

5.4 Threats to Validity 93

$\begin{array}{ll}5.5 \text { Summary } & 94\end{array}$

6 Final Remarks and Future Work 96

6.1 Limitations and Future Work 98 


\section{List of Figures}

2.1 Source code instantiating Spring-provided concepts and their assignment to features.

2.2 Source code instantiating Jadex-provided concepts and their assignment to features.

2.3 Configuration and customization Code. 23

2.4 Spring constructor-based dependency injection. 24

2.5 Cross-references between concept instances. 25

2.6 Source code of mutually exclusive concepts instances. 26

2.7 References to concept instances inside customization code. 27

2.8 Context sensitive instantiation constraints. 29

2.9 WeatherService instantiation code annotated with features. 31

2.10 User agent and Event Scheduler capability instantiation codes annotated with features. 32

2.11 Software product line architecture defined in pure::variants. 33

3.1 Ecore language structure. 41

3.2 Exemplar Spring Domain Knowledge Modeling Language. 42

3.3 Exemplar Spring Domain Knowledge Model. 43

3.4 Spring Domain Knowledge Modeling Language with references. 44

3.5 Spring Domain Knowledge Model with references. 45

3.6 Spring Domain Knowledge Modeling - Bean EventDAO. 48

3.7 Detailed creation of Spring-DKM following the guidance rules. 54

4.1 GenArch ${ }^{+}$architectural overview. $\quad 59$

4.2 Domain Knowledge Schema 61

4.3 GenArch ${ }^{+}$reflective DKML editor. $\quad 62$

4.4 Filtered exemplar Spring-DKML 63

4.5 WeatherService occurrence marked. 63

4.6 Reference View: references to the Bean WeatherService 64

4.7 Usage View: usage of the Belief client 64

4.8 Spring-DKML mappings patterns. 68

5.1 Box plot for correctness. $\quad 81$

5.2 Box plot for time. $\quad 82$

5.3 Measure of Correct Answers 84

5.4 Measure of Correct Answers and Expertise 85

5.5 Box plot for correctness. $\quad 86$

5.6 Box plot for time. $\quad 88$

5.7 Measure of correct answers per tasks. $\quad 90$

5.8 Measure of time per tasks. 91

5.9 Box plot for difficult - Tasks T1 and T2. 92

5.10 Box plot for difficult - Tasks T3 and T4. 93 


\section{List of Tables}

2.1 Results of computed metrics. 21

2.2 Benefits and limitations of annotation and model-based techniques. 36

4.1 Mapping Types 66

5.1 Main characteristics of the target product lines. 71

5.2 Configuration Knowledge Modularization - separation of concerns metrics. 74

5.3 Configuration Knowledge Modularization - size metrics. 75

5.4 Degree of Expertise of the participants 78

5.5 Description of the second comprehension questionnaire. 79

5.6 Latin Square configuration 79

5.7 ANOVA test for participants time. 81

5.8 Descriptive statistics of the experimental results. 87

5.9 ANOVA test for participants answers. 87

5.10 Tukey's HSD multiple comparison test results for answers. $\quad 87$

5.11 Descriptive statistics (Answers and Time) - Task $1 \quad 90$

5.12 Descriptive statistics (Answers and Time) - Task 2

5.13 Descriptive statistics (Answers and Time) - Task $3 \quad 92$

5.14 Descriptive statistics (Answers and Time) - Task 4 